\title{
Videotaped Instruction and Constructivist Model On Students' Physics Achievement
}

\author{
Agommuoh, Patience Chinyere (Ph.D) \\ Department Of Science Education, College Of Agricultural And Science Education, Michael Okpara University \\ Of Agrculture P.M.B 7267, Umudike Umuahia, Abia State, Nigeria
}

\begin{abstract}
This study was designed to explore the effects of videotaped instruction and the five steps constructivists' model of prior knowledge, exploration, discussion, dissatisfaction with prior knowledge and application (PEDDA) on the achievement of students in physics. A quasi-experimental design involving pretest and posttest for both experimental groups was employed. The sample size was 398 (videotaped group =198, PEDDA group = 200). Senior secondary school two (SSS2) physics students from four co-educational schools were randomly selected out of the sixteen coeducational schools in Umuahia North Local Government Area (LGA) of Umuahia Education Zone of Abia State Nigeria. Two of the schools were randomly assigned to videotaped treatment group and the other two to PEDDA treatment group. Students in both groups were given pretest before instruction and posttest after instruction. Data was obtained using Physics Concept Test (PCT). The instrument PCT used for data collection was validated by experts of measurement and evaluation in the Department of Science Education of Michael Okpara University of Agriculture, Umudike. Data collected was analyzed using mean, standard deviation and analysis of covariance. The study revealed that both treatment groups facilitated achievement among students with PEDDA constructivist model facilitating achievement better than videotaped instruction. Recommendations were made.
\end{abstract}

Keywords: Achievement, constructivism, constructivist model, physics and videotaped instruction,.

\section{Introduction}

The knowledge of the natural world and environment has led to the division of the natural sciences into several disciplines of which physics is one of them. Physics is a science that observes natural phenomena and explains them by using general rules to describe what has been observed. According to Ayodele and Anyaegbuna (2012), today's physics has two sides, on the one hand, it provides the basis for our current world picture, while on the other hand, it is the foundation of other subjects for technological developments. In the view of Esiobu (2007), of the three core sciences-Biology, Chemistry and Physics, physics holds the strongest position as a major subject prerequisite into careers in science and technology. Physics has helped in the development of modern technology through the application of its principles to modern invention. It enhances an understanding of the interplay of forces in nature. Adeyemi (2003) and Oraifo (2005) are of the view that physics plays very important role in scientific and technological advancement that affect the lives of mankind. The implication is that the outcomes of physics education affect the attainment and realization of our national goals and objectives with regards to the development of science and technology in Nigeria (Ayodele \& Anyaegbuna, 2012). In other words, Nigeria cannot develop technologically if physics is not taught properly at the secondary school level.

Despite all the efforts made by the Federal Government and physics educators to improve the teaching of physics, physics learners have been observed to demonstrate low achievement in physics examinations (Oraifo, 2005). Empirical evidences revealed that students' scientific literacy levels are low and that students have difficulties mastering the concepts and principles outlined in the science curricula especially in physics (Njoku, 2002; Eze, 2003; Nwagbo, 2006). Poor performance in physics and its effect on the scientific and technological development of the country has been the major concern of many physics educators. These poor performances as observed over the years could be as a result of the methods used in the teaching of physics which has made the subject very unpopular on the part of the students (Ayodele, 2002). Hence the need to explore the effects of videotaped instruction and the five step constructivist model (PEDDA) on physics students' achievement since researchers have indicated that science learning is a constructive process and knowledge construction which requires participation on the part of the learner and their teacher (Achor, 2001).

Videotaped instruction is an instructional tool that has high potential in the teaching and learning situations. Videotapes have the quality of being able to provide semi permanent, very complete and audio-visual records of events. They have the potential of increasing the probability that students will learn more, retain better and even improve their performance of the skills they are expected to develop. Educational technologists as well as curriculum experts have proved that videotaped instruction has high potential in the teaching and learning situation for it can multiply and widen the channels of communication between the teacher and the 
students (Osokoya, 2007; Curzon, 1991). Adams (1990) is of the opinion that videotaped instruction is one of the most influential of all the media for teaching as a result of its power of both sight and sound. Banford and Western (1997) reiterated that the benefits of colour, sound and motion attached to the videotaped packed will be of interest to the students who are the target of the study. Literature has also established that videotaped instruction has greatly improved the performance of children with special needs and slow learning abilities (Aremu, 1992; Mitchell, 1994; Okwo, 1994).

Constructivism is a teaching approval that holds the view that knowledge are personally constructed and reconstructed by the learner based on his prior knowledge or experience. Learners are viewed as active participants in the learning process and are said to construct meaning through experiences thereby developing personal theories about the physical and social world. The Five Step Conceptual Change Instruction Model (PEDDA) was developed by Nworgu (1996) PDDA is a five step conceptual change instructional model which comprises prior knowledge, exploration, discussion, dissatisfaction with the prior knowledge and application. This model provides the opportunity for the learner to test his perceptions against actual experience from his own activities and apply the new experiences in order to experience its usefulness. The model also provides an outline for instructors who wish to combine the development of reasoning and content mastery.

The influences of students gender in their achievement in physics has been a concern to education researchers for long. Some studies showed that male students achieve better than female students in physics (Ogu, 1995; Madu, 2004; and Ogbonna, 2004). Other studies showed that female students achieve better than male students (Ocho, 1997; Nkpa 1997). In the studies carried out by Ifeanacho (2002), Aiyedun (2000) and Agommuoh (2004) gender was found to play no significant role in physics achievement. This makes gender issues inconclusive.

\section{Purpose of the Study:}

The purpose of this study is to investigate the effects of videotaped instruction and the five step constructivist model (PEDDA) on secondary school students' achievement in physics.

\section{Research Questions}

The following research questions guided the study:

1. What are the mean achievement scores of students taught physics using videotaped instruction and those taught using PEDDA methods?

2. What are the mean achievement scores of male and female students taught physics using videotaped instruction and those taught using PEDDA methods?

\section{Hypotheses}

The following null hypotheses tested at $\mathrm{P} \leq 0.05$ guided the study.

Ho $_{1}$ : There is no significant difference in the mean achievement scores of Students' taught physics using videotaped instruction and those taught using PEDDA method.

$\mathbf{H O}_{2}$ : There is no significant difference in the mean achievement scores of male and female students taught physics using videotaped instruction and those taught using PEDDA method.

\section{Methodology}

The study adopted the quasi-experimental research design. Specifically the study was non-randomized pretest posttest control group design. This design was chosen because intact classes were used for the study.

Umuahia North Local Government Area of Umuahia Education Zone of Abia State was purposively sampled because it has the highest number of coeducation secondary schools in the zone. Four coeducational secondary schools in Umuahia North LGA were selected. Out of the four schools selected, two were randomly assigned to videotaped treatment group and two to PEDDA treatment. A total of three hundred and ninety-eight (398) Senior Secondary School two (SSS2) physics students (videotaped group $=198$, PEDDA group $=200$ ) formed the sample for the study.

The instrument used in this study is Physics Concept Test (PCT). The PCT was in form of paper and pen test that included 10 questions in essay format which measured the students' knowledge and subsequent understanding and application of physics concepts. Students in both groups were given pretest before instruction and posttest after instruction. A videotaped was used to capture important a characteristic of the lesson taught as the teacher was teaching it and this was played to the students. In the case of the constructivist model, students' prior conceptions were diagnosed; materials that will enable them observe phenomenon provided, scientific information that will enable them arrive at scientifically acceptable explanation of concepts created and opportunities to develop the fruitfulness by applying the new concepts to real world situations provided to the students. 
The instrument PCT used for data collection was validated by three experts of measurement and evaluation and physics educators of Michael Okpara University of Agriculture, Umudike. An internal reliability of 0.80 was obtained using cronbach Alpha while the coefficient of stability for the PCT was established using spearman's test-retest coefficient of reliability and was found to be 0.91 . Data collected was analyzed using mean and standard deviation for the research questions, analysis of covariance for the hypotheses.

The research questions were answered by computing the mean scores and standard deviation scores nof both groups while the hypotheses were tested at $\mathrm{P} \leq 0.05$ probability level using analysis of covariance.

\section{Results}

The result in respect of mean and standard deviation of students overall achievement scores used in answering research questions 1 and 2 is shown in table 1 .

Table 1:

Mean and Standard Deviation of Students' Overall Achievement Scores using Videotaped Instruction and PEDDA Method

\begin{tabular}{lccccccc} 
Method & Gender & \multicolumn{3}{c}{ Pretest } & \multicolumn{4}{c}{ Posttest } \\
& & Mean & SD & \multicolumn{2}{c}{ Mean } & \multicolumn{3}{c}{ SD } & N \\
& Male & 13.33 & 3.75 & 99 & 26.33 & 4.67 & 99 \\
PEDDA & Female & 12.96 & 3.25 & 101 & 26.28 & 3.90 & 101 \\
& Overall & 13.18 & 3.56 & 200 & 26.31 & 4.37 & 200 \\
& Male & 14.82 & 3.92 & 102 & 24.51 & 4.17 & 102 \\
Videotaped & Female & 12.85 & 3.30 & 96 & 23.95 & 4.17 & 96 \\
& Overall & 14.04 & 3.80 & 198 & s24.29 & 4.16 & 198
\end{tabular}

The result in table 1 clearly showed that the mean achievement scores of PEDDA group were higher than that of students in the Videotaped group. Table 1 also showed that male students in both groups scored higher than their female counterparts.

The ANCOVA results in respect of students' overall achievement scores by instructional approaches and gender used in answering hypotheses 1 and 2 is shown in table 2 below.

Table 2

Analysis of Covariance of Students' Overall Achievement Scores by Instructional Approaches and Gender

$\begin{array}{lccccc}\begin{array}{c}\text { Source of } \\ \text { Variance }\end{array} & \begin{array}{c}\text { Sum of } \\ \text { Squares }\end{array} & \text { Df } & \begin{array}{l}\text { Mean } \\ \text { Squares }\end{array} & \text { F } & \text { Sign of P } \\ \quad \begin{array}{l}\text { Model } \\ \text { PREACHVT }\end{array} & 256325.329 & 5 & 51265.065 & 3388.712 & .000 \\ \text { (Covariates) } & 1217.816 & 1 & 1217.816 & 80.025 & .000 \\ \text { METHOD } & 548.024 & 1 & 548.024 & 36.012 & .000 \\ \text { SEX } & 6.213 & 1 & 6.213 & .408 & .523 \\ \text { METHOD* SEX } & 1.682 & 1 & 1.612 & .111 & .740 \\ \quad \text { Error } & 5980.675 & 393 & 15.218 & & \\ \text { Total } & 162306.000 & 398 & & & \end{array}$

Table 2 above shows the ANCOVA results of students who were taught with PEDDA and videotaped instructions. From table 2, the main effect was significant as well as treatment. Thus the null hypothesis of no significant difference in students' achievement was rejected. Hence there is a significant difference in students' achievement. The main effect was found significant while gender was not significant. Thus the null hypothesis of no significant difference for gender was not rejected since sex was not significant.

\section{Discussion}

The mean achievement scores of students taught with both PEDDA method and videotaped instruction was found to improve with that of those taught with PEDDA method higher than that of those taught with video taped instruction. This implies that PEDDA method facilitated students' achievement of physics concepts better than the videotaped instruction. This is because PEDDA method provides the students with a lot of time, productive engagement and facilities that makes it possible for information to be obtained through activities that proceeds through a planned sequence of structured concept invention and concept application activities. This result is in consonance with the opinion of Okebukola (2002) that the learner advances through Assimilation, 
Accommodation and Equilibrium. This is also in agreement with the opinion of Rollink and Rutherford (1993) that the use of constructivists' strategy was effective in facilitating conceptual shift. The result of this study is also in agreement with the works of Egbughara (1988), Obodo (1990) and Madu (2004). Egbughara (1988) observed that the use of advanced organizers in teaching had significant achievement effect in science learning. Obodo (1990) noted that three instructional strategies (target tasks, delayed formalization and expository) methods had significant effect on achievement of algebraic concepts while Madu (2004) in his work found out that constructivist based methods are significant in enhancing achievement.

From the result, both male and female students improved in their achievement scores but with male students having slightly higher mean achievement scores than their female counterparts. This result agrees with the findings of some studies (Madu, 2004; Agommuoh, 2004; Ogbonna, 2007) which indicated that there was no significant difference between achievement of male and female students in science learning.

\section{Conclusion}

The use of both PEDDA and videotaped methods improved students' achievement in physics but with the use of PEDDA constructivist instructional method enhancing students' achievement in physics concepts better than the videotaped method. Gender had no influence over achievement although male students seemed to perform better than their female counterparts relative to their achievement scores in physics concepts.

\section{Recommendation}

It is recommended that classroom teachers should design teaching strategies that can help students overcome their difficulties in learning and interpreting physics concepts. The PEDDA and videotaped methods of teaching physics should be adopted in secondary schools. Physics teachers should be trained on the effective use of such methods through seminars, workshops and conferences. Curriculum developers in science education should adopt these methods in restructuring the physics curriculum in our secondary schools. It is therefore expected that with improved scores in physics, the much expected scientific literacy and technological development may become a reality.

\section{References}

[1]. O. Ayodele, \& B. Anyaegbuna, An assessment of physics audiovisual teaching and learning resources at the tertiary level, in Lagos and Ogun States. Proceedings of the $43^{\text {rd }}$ STAN Annual Conference and InauguralConference of CASTME Africa, $2012,358-366$.

[2]. G. O. Esiobu, Gender issues in science and technology education ( Ivowi U. M. O. (Ed) Science and Technology Education for Development, Lagos, Adeccos Education Science Ltd, 2007.

[3]. S.O. Adeyemi, Studies of the effect of aptitude instructional leadership style and Learning Environment on Students Achievement in Physics. Unpublished Ph. D. thesis, University of Lagos, Nigeria 2003.

[4]. S. O. Oraifo, Teaching methodologies in science and technology education, In Education for Development Lagos NERDC Press, $2005,1-24$.

[5]. Z. C. Njoku, Nigerian university non- science students' level of scientific literacy as indicator of national readiness of sustainable development. The case of the University of Nigeria, Nsukka. Proceedings of the $43^{\text {rd }}$ Annual Conference of Science Teachers Association of Nigeria, 2002, 69-72.

[6]. C. U. Eze, An investigation into the scientific literacy level of non science students of Nigerian universities: A case study of University of Nigeria, Nsukka. Journal of Science Teachers Association of Nigeria 2003, 38 (1\&2) 51-57.

[7]. C. R. Nwagbo, Effects of two teaching methods on the achievement in and attitude to Biology of students of different levels of scientific literacy. International Journal of Education Research, 2006, 216-229. www.elsevier.com/locate/ijedures

[8]. E. A Ayodele, Obstacles to the effective teaching and learning of chemistry at the secondary school level: Curriculum implications for sustainable educational development. In Akale (ed) STAN Proceedings of the $43^{\text {rd }}$ Annual Conference and Inaugural Conference of CASTME Africa. 2002,539-542.

[9]. E.E. Achor,. Students' cognitive style, cognitive development and cognitive demands of secondary physics. 2001, Unpublished Ph. D Thesis, University of Nigeria, Nsukka.

[10]. I. O. Osokaya, Effects of videotaped instruction on secondary school students' achievement in History. International Journal of African and African American studies 5(1), 2007.

[11]. L. B Curzon,. Teaching in further education. London: Cassell Educational Ltd, 1990.

[12]. D. Adams, Connecting video segments to collaborative learning activities. Educational media international 1(27), 1990, $158-163$.

[13]. J. Banford, \& C. Western, The use of video as a teaching resource in a new University. British Journal of Education Technology 28 (1). 1997.

[14]. S. A. Aremu, The need, usefulness of instructional materials for meaningful teaching and learning. Journal of studies in curriculum. 3 (1\&2) Lagos: Academic Publications Association of Nigeria,1992.s

[15]. N. I. Mitchell, \& S. J. Surprice, Effective use of video interactive modules. Proceedings on World Conference on Educational Multi-media and hypermedia. Vancower, Canada, 1994, 25-30.

[16]. F. A. Okwo, Appropriate media technique for rural development communication and education in Nigeria. Journal of Quality Education. 1 (1), 1994, 36- 45.

[17]. B. G. Nworgu, Teaching for conceptual understanding in physics. A conceptual change instructional model. A paper presented at the $37^{\text {th }}$ Conference of Science Teachers Association of Nigeria (STAN), Uyo, 1996.

[18]. M. N.A. Ogu, Relationship between classroom environment and students' achievement in the secondary school physics. Unpublished ME.d thesis, University of Nigeria, Nsukka, 1995.

[19]. B.C. Madu, Effects of Constructivist-Based instructional Model on Students' conceptual change and retention in physics. An unpublished Ph. D thesis, university of Nigeria Nsukka, 2004. 
[20]. C.C. Ogbonna, Effects constructivists instructional approach on senior secondary school students'achievement and interest in mathematics. An Unpublished Ph.D Thesis,University of Nigeria, Nsukka,2004.

[21]. R. A. Ocho, Gender valuation of Science and Technology education among secondary school students in Enugu urban. In G. A. Badmus and L.O. Ocho (ed). Science, 1997, 207-219.

[22]. M. Nkpa, Gender and performance in SSCE Science and Mathematics in Okigwe L.G.A. (1990 - 1994).Journal of Creating in teaching for the acquisition and dissemination of effective learning. 1 (2), 1997, 345- 354.

[23]. A. O. Ifeanacho, Errors committed and the effect of calculating devices on students mathematics achievement in Umuahia education zone. Unpublished Med thesis, University of Nigeria, Nsukka, 2002.

[24]. J. O. Aiyedun, Influence of sex difference of students' achievement in secondary school mathematics. ABACUS. Journal of the Mathematical Association of Nigeria. 25 (1), 2000, 102 -113 mathematics education series.

[25]. P. C. Agommuoh, Effects of videotaped instruction on secondary school students physics. Unpublished school students physics. Unpublished MED thesis, University of Nigeria, Nsukka, 2004.

[26]. P.A.O. Okebukola, Some factors Associated with Effective Learning of Physics in Anambra State Secondary Schools in Nigeria. Nigeria Educational Forum 12 (7), 2004, 49-70.

[27]. M. Rollink, \& M. Rutherford,The use of a conceptual change model and mixed language for remediating misconceptions on air pressure. International Journal of Science Education. 15 (4),1993, 363- 381.

[28]. U. O. Egbughara, The retentive effects of three modes of advance organizer. Institute Journal of Studies in Education. 1 (1), $1988,112-118$

[29]. G. C. Obodo, The differential effects of the teaching models on the performance of Junior Secondary School students in algebraic concepts. Unpublished Ph.D Thesis, University of Nigeria, Nsukka, 1990.

[30]. C. C. Ogbonna, Effects of two Constructivists Instructional Models On students' achievement and retention in number and numeration. An Unpublished Ph.D Thesis, University of Nigeria, Nsukka, 2007. 